\title{
Postoperative pain inhibition by preoperative methylprednisolone in open cholecystectomy with the assessment of IL-6 and PGE
}

Suwarman and Hendro Sudjono Yuwono*

*Correspondence: hsyabc47@gmail.com

School of Medicine, Padjadjaran University, Bandung, Indonesia.

\begin{abstract}
Background: Open cholecystectomy is an operation which is often carried out with the aim of removing the gallbladder. In this operation an incision was performed along a 10-15 cm line in the right subcostal or midline area under the epigastric area. Here postoperative pain is a common problem that must be taken into consideration. $\mathrm{PGE}_{2}$ and IL-6 are the predominant cytokines that are released after trauma from surgery and associated with inflammation of pain. Methylprednisolone is a glucocorticoid that has been reported to reduce postoperative pain in addition to inhibiting hyperalgesia of inflammatory mediator IL-6 and $\mathrm{PGE}_{2}$.
\end{abstract}

Material and methods: The level of pain was assessed during the 1 st hour of surgery, the $2^{\text {nd }}, 4^{\text {th }}, 8^{\text {th }}, 12^{\text {th }}$ and $24^{\text {th }}$ hour consecutively. $125 \mathrm{mg}$ of methylprednisolone was injected intravenously 60 minutes before the operation and 30 minutes before completing the skin sutures. For Group I: methylprednisolone was given postoperatively; Group II: methylprednisolone was given before surgery; and for Group III, the Control Group. Each Group number included a sample of 10 patients with the following inclusion criteria: ASA clinical classification I-II, age 20-60 years.

Results: The study showed that the treatment reduced postoperative IL-6 levels significantly $(\mathrm{p}=0.0000)$, except in the $24^{\text {th }}$ hour $(\mathrm{p}=0.4999)$. The postoperative $\mathrm{PGE}_{2}$ was not significantly changed $(\mathrm{p}>0.05)$.

Conclusion: The levels of IL-6 in open cholecystectomy that were given methylprednisolone intravenously preoperatively were lower than given postoperatively, but were not reduced for the $\mathrm{PGE}_{2}$ level. Methylprednisolone administered intravenously before open cholecystectomy is able to decrease postoperative pain.

Keywords: Methylprednisolone, open cholecystectomy, IL-6, PGE ${ }_{2}$

\section{Introduction}

Postoperative pain occurs after open cholecystectomy. The pain is caused by stimulation of sensory nerves in injured soft tissue, particularly in the area where the skin incision occurs. The inflammatory pain occurs due to tissue damage that causes an inflammatory response caused by the release of a local mediator with systemic effect [1]. These mediators include IL-6 and $\mathrm{PGE}_{2}[\mathbf{1}, \mathbf{2}]$. The presence of inflammatory mediators contributed to the occurrence of postoperative pain. Methylprednisolone has the effect of inhibiting the formation of pro-inflammatory cytokines production by macrophages and mast cells, which then prevents cyclooxygenase from occurring [3]. Formation of cyclooxygenase leads to changes in arachidonic acid and to prostaglandins, which then prevents painful stimuli from occurring [3]. Are there differences in the levels of $\mathrm{PGE}_{2}$ and
IL-6 after open cholecystectomy surgery among patients given intravenous methylprednisolone before and after surgery?

\section{Materials and methods}

Patients

Patients were those undergoing open cholecystectomy surgery, ASA clinical classification I-II, age 20-60 years. We exclude patients with chronic pain, females with positive pregnancy test results, anyone taking long-term glucocorticoid, people with drug hypersensitivities to methylprednisolone, patients with diabetes mellitus, and those who would undergo cholecystectomy surgery that would last for more than 4 hours.

\section{Ethical clearance}

This clinical trial has been approved by the Research Ethics 
Committee of the School of Medicine, Padjadjaran University. After all procedures have been explained in detail, all participant-patients should eventually signed the consent form.

\section{Glucocorticoid}

Methylprednisolone 125mg (Medixon, Ferron) was injected intravenously at 60 minutes before the operation and 30 minutes before completing the skin sutures.

\section{Open cholecystectomy}

Open cholecystectomy surgery is a gallbladder excision in patients with gallstone disorder or who have an infection in the gallbladder, which is done along a $10-15 \mathrm{~cm}$ line in the right subcostal area or in the midline incision.

\section{Anesthetic procedures}

Sixty minutes before anesthetic-induction, intravenous 125 mg methylprednisolone (Group II) was given preoperatively, while in the postoperative methylprednisolone group (Group I) and the control group (Group III), $1 \mathrm{cc} 0.9 \% \mathrm{NaCl}$ was given intravenously. Induction of anesthesia in both groups carried out by administering $2-3 \mathrm{mg} / \mathrm{kg}$ body weight of propofol. The patients were ventilated with $\mathrm{N} 2 \mathrm{O} / \mathrm{O} 2=50 \%: 50 \%$, and $2 \%$ volume isoflurane. General anesthesia involved an Isoflurane vaporizer and anesthesia machine (Draeger) with nitrous oxide, oxygen, isoflurane and atracurium. Intravenous fentanyl dosage $1-3 \mathrm{mg} / \mathrm{kg}$ body weight were used for analgesia during surgery.

\section{IL-6 and PGE 2 kits}

Human IL- 6 and PGE 2 kits, determined using ELISA, were bought from R\&D system, USA.

\section{Statistical analysis}

This clinical trial was a double blind randomized controlled trial of patients undergoing open cholecystectomy surgery in general anesthesia. Permuted-block randomization were used.

A one-way anova test was used when the data were normally distributed, but when the data were not normally distributed a Kruskal-Wallis test was used instead. A Shapiro-Wilk test will be used for normal distribution testing. Data analysis was performed using SPSS for Windows version 13.0 on a confidence interval level of $95 \%$ with a regarded significant value of $p<0.05$.

\section{The sample size used the following formula}

$$
n=\frac{2(\mathrm{Sd})^{2}(\mathrm{Z} \alpha+\mathrm{Z} \beta)^{2}}{E^{2}}
$$

$\mathrm{n}=$ sample size; $\mathrm{Sd}=$ standard deviation; $\mathrm{E}=$ effect size; $\mathrm{Z} a$ and $Z \beta$ are the value obtained from the normal distribution table. Based on the above formula a minimum sample size $n=8$ was obtained, so the conclusion was to use a sample number of 10 .

\section{Results}

Patient's characteristics

All parameters in Table 1 shows a not significance value ( $p>0.05$ ). All patients with HARS $<5$ were participants who did not have any anxiety condition.

Table 1. Distribution of patient's characteristic.

\begin{tabular}{l|lll|l}
\hline $\begin{array}{l}\text { Patient's } \\
\text { characteristic }\end{array}$ & \multicolumn{3}{|c|}{ Grouping } & P-value \\
\cline { 2 - 4 } & $\begin{array}{l}\text { I } \\
(\mathbf{n}=\mathbf{1 0})\end{array}$ & $\begin{array}{l}\text { II } \\
(\mathbf{n}=\mathbf{1 0})\end{array}$ & $\begin{array}{l}\text { III } \\
(\mathbf{n}=\mathbf{1 0})\end{array}$ & \\
\hline $\begin{array}{l}\text { Gender: } \\
\text { Man }\end{array}$ & 6 & 6 & 6 & 1.000 \\
Woman & 4 & 4 & 4 & -- \\
Age (year) : & & & & \\
Standard Dev. & $42.6(13.5)$ & $52.8(11.8)$ & $54.2(11.2)$ & 0.085 \\
Median & 45 & 53 & 53 & -- \\
Range & $22-68$ & $30-72$ & $38-73$ & -- \\
Education : & 2 & 4 & 5 & 0.710 \\
High school & 4 & 3 & 2 & -- \\
University & 4 & 2 & 3 & -- \\
HARS: & & & & \\
Median & 3.5 & 3 & 3 & $0.016^{\#}$ \\
Rentang & $3-4(\mathrm{a})$ & $2-4(\mathrm{ab})$ & $2-3(\mathrm{~b})$ & -- \\
\hline
\end{tabular}

All were calculated by using the Chi-square test, except for age by t-test.

Group I: Postoperative methylprednisolone;

Group II: Preoperative methylprednisolone;

Group III: Control.

HARS-Hamilton Anxiety Rating Scale

\section{Blood level IL- 6 concentration}

Table 2 shows preoperative intravenous methylprednisolone given resulted in a significant decrease of postoperative IL-6 concentration.

The results from Table 3 confirmed the results from Table 2 i.e., the significantly decreased level of IL- 6 concentration in the $1^{\text {st }}, 4^{\text {th }}, 24^{\text {th }}$ hour postoperation.

\section{Blood concentration level of $\mathrm{PGE}_{2}$}

The results show in Tables $\mathbf{4}$ and $\mathbf{5}$ show that the postoperative concentration of $\mathrm{PGE}_{2}$ was higher than the preoperative concentration of $\mathrm{PGE}_{2}$.

\section{Discussion}

Preoperative steroid administration can lower the intensity of the postoperative pain. In suppressing postoperative pain, glucocorticoids like methylprednisolone or dexamethasone have been scientifically investigated to show that one preoperative single dose was having many advantages in reducing postoperative pain. A clinical investigation by Musba et al., (2015) showed that the 15 patients who received preoperative combination of $8 \mathrm{mg}$ dexamethasone, paracetamol and morphine, had not had their IL- 6 and IL-10 levels increase in immediate post-surgery and 24 -hours post-operation periods [4]. The glucocorticoids have a mechanism through which 
Tabel 2. IL-6 concentration of all Groups.

\begin{tabular}{|c|c|c|c|c|}
\hline \multirow[t]{2}{*}{ IL-6 (ng/mL) } & \multicolumn{3}{|c|}{ Grouping } & \multirow[t]{2}{*}{$\mathbf{P}^{*}$-value } \\
\hline & $\begin{array}{l}\text { I } \\
(n=10)\end{array}$ & $\begin{array}{l}\text { II } \\
(n=10)\end{array}$ & $\begin{array}{l}\text { III } \\
(n=10)\end{array}$ & \\
\hline Preop.(Sd) & $5.91(8.13)$ & $35.47(43.68)$ & $17.34(26.98)$ & 0.044 \\
\hline Median & 2.49 & 12.14 & 4.79 & -- \\
\hline Range & $0.95-28.05$ & $1.61-140.0$ & $0.39-68.7$ & -- \\
\hline 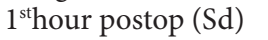 & $65.30(31.22)$ & $22.13(13.68)$ & $61.04(46.74)$ & 0.013 \\
\hline Median & 64.05 & 18.91 & 47.07 & -- \\
\hline Range & $21.61-106.28$ & $5.89-50.33$ & $5.30-140.0$ & -- \\
\hline 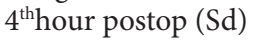 & $18,46(13.24)$ & $13.62(7.78)$ & $39.48(21.69)$ & 0.002 \\
\hline Median & 17.75 & 13.5 & 38.1 & -- \\
\hline Range & $1.10-49.82$ & $3.6-24.9$ & $4.36-78.07$ & -- \\
\hline $24^{\text {th hourpostop }(\mathrm{Sd})}$ & $24.65(22.04)$ & $16.65(15.21)$ & $43.53(39.10)$ & 0.066 \\
\hline Median & 16.78 & 10.66 & 29.53 & -- \\
\hline Range & $1.80-76.82$ & $2.88-44.31$ & $5.63-128.8$ & -- \\
\hline
\end{tabular}

Results of F test (Anova), except $1^{\text {st }}$ hour, $24^{\text {th }}$ hour Kruskal-Wallis test.

Group I: methylprednisolone given postoperatively

Group II: methylprednisolone given preoperatively

Group III: Control Group; (Sd)=(Standard deviation)

Tabel 3. Comparison IL-6 concentration between Groups.

\begin{tabular}{|c|c|c|c|c|}
\hline \multirow{2}{*}{$\begin{array}{l}\text { IL-6 concentration } \\
(\mathrm{ng} / \mathrm{ml})\end{array}$} & \multicolumn{3}{|c|}{ Grouping } & \multirow[t]{2}{*}{ P-value } \\
\hline & $\begin{array}{l}I \\
(n=10)\end{array}$ & $\begin{array}{l}\text { II } \\
(n=10)\end{array}$ & $\begin{array}{l}\text { III } \\
(n=10)\end{array}$ & \\
\hline Preop $-1^{\text {st }}$ hour postop & -59.39 & 13.34 & -43.70 & 0.001 \\
\hline Preop- $4^{\text {th }}$ hour postop & -12.55 & 21.85 & -22.14 & 0.001 \\
\hline Preop-2 $4^{\text {th }}$ hour postop & -18.74 & 18.82 & -26.19 & 0.003 \\
\hline $1^{\text {st }}$ hour- $4^{\text {th }}$ hour postop & 46.84 & 8.51 & 21.56 & 0.010 \\
\hline $1^{\text {sthour- }} 24^{\text {th }}$ hour postop & 40.65 & 5.47 & 17.52 & 0.113 \\
\hline $4^{\text {th }}$ hour- $24^{\text {th }}$ hour postop & -6.19 & -3.03 & -4.05 & 0.849 \\
\hline
\end{tabular}

Kruskal-Wallis test.

GroupI: postoperative methylprednisolone

Group II: preoperative methylprednisolone

Group III: control

Preop $=$ preoperation; postop $=$ postoperation. inhibition of cyclooxygenase which reduces the synthesis of prostaglandins, particularly $\mathrm{PGE}_{2}$, in attenuating pain [5]. Thus, $\mathrm{PGE}_{2}$ is an inflammatory cytokine that lowers pain threshold $[5,6]$. In the literature we found that in surgery the IL- 6 triggers the release of $\mathrm{PGE}_{2}$ from macrophages. PGE2 is potentially the most potent endogenous immunosuppressant, as it does suppress T-cell and macrophage responsiveness, it also induce IL-10 as a potent cytokine that deactivates monocytes $[6,7]$. In clinical cases the IL-6 levels correlate with Injury Severity Score (ISS) and the development of multiple organ failure, acute respiratory distress syndrome (ARDS) and septicaemia as well [7].

In this study, the postoperative production of IL-6 significantly decreased as a result of administrating methylprednisolone preoperatively, but it did not reduce the levels of $\mathrm{PGE}_{2}$. The $P \mathrm{PE}_{2}$ is an

Table 4. $\mathrm{PGE}_{2}$ concentration.

\begin{tabular}{|c|c|c|c|c|}
\hline \multirow{2}{*}{$\begin{array}{l}\mathrm{PGE}_{2}(\mathrm{pg} / \mathrm{mL}) \\
\text { in plasma }\end{array}$} & \multicolumn{3}{|c|}{ Grouping } & \multirow[t]{2}{*}{ p-value } \\
\hline & $\begin{array}{l}\text { I } \\
(n=10)\end{array}$ & $\begin{array}{l}\text { II } \\
(n=10)\end{array}$ & $\begin{array}{l}\text { III } \\
(n=10)\end{array}$ & \\
\hline Preop.(Sd) & $711.5(1551.8)$ & $2459.7(1765.9)$ & $2581.0(1506.3)$ & 0.179 \\
\hline Median & 3994.8 & 2746.9 & 2593.6 & -- \\
\hline Range & $1635.2-5951.7$ & $92.7-5309.2$ & $259.7-5446.7$ & -- \\
\hline 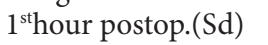 & $2278.7(1314.4)$ & $1792.9(1015.0)$ & $2630.9(1285.4)$ & 0.316 \\
\hline Median & 2345.6 & 1696.6 & 2734.0 & -- \\
\hline Range & $196.8-4306.7$ & $120.8-3706.8$ & $819.9-4254.1$ & -- \\
\hline 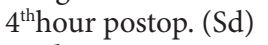 & $3077.3(1432.7)$ & $1570.4(830.0)$ & $2772.0(1220.8)$ & 0.032 \\
\hline Median & 3260.6 & 1521.0 & 2303.6 & -- \\
\hline Range & $374.6-4629.3$ & $362.1-2749.0$ & $1635.2-4702.6$ & -- \\
\hline $24^{\text {th hourpostop. (Sd) }}$ & $2767.8(926.4)$ & $1786.4(1092.8)$ & $2572.4(1552.0)$ & 0.182 \\
\hline Median & 2618.6 & 1675.8 & 2739.6 & -- \\
\hline Range & $1670.8-4574.7$ & $92.7-3713.5$ & $92.7-5173.4$ & -- \\
\hline
\end{tabular}

Kruskal-Wallis test.

Group I: postoperative methylprednisolone

GroupII: preoperative methylprednisolone

Group III: control; $(\mathrm{Sd})=($ Standard deviation $)$ 
Suwarman et al. Journal of Anesthesiology \& Clinical Science 2016,

Table 5. PGE .

\begin{tabular}{|c|c|c|c|c|}
\hline \multirow[t]{2}{*}{$\mathrm{PGE}_{2}(\mathrm{pg} / \mathrm{ml})$} & \multicolumn{3}{|c|}{ Grouping } & \multirow[t]{2}{*}{ p-value ${ }^{*}$} \\
\hline & $\begin{array}{l}I \\
(n=10)\end{array}$ & $\begin{array}{l}\text { II } \\
(n=10)\end{array}$ & $\begin{array}{l}\text { III } \\
(n=10)\end{array}$ & \\
\hline Preop - $1^{\text {st }}$ hour postop & 1432.7 & 666.7 & -49.8 & 0.027 \\
\hline Preop - $4^{\text {th }}$ hour postop & 634.1 & 889.3 & -191.0 & 0.195 \\
\hline Preop - $24^{\text {th }}$ hour postop & 943.7 & 673.2 & 8.6 & 0.350 \\
\hline $1^{\text {st }}$ hour $-4^{\text {th }}$ hour postop & -798.6 & 222.6 & -141.2 & 0.127 \\
\hline $1^{\text {sth }}$ our $-24^{\text {th }}$ hour postop & -489.1 & 6.5 & 58.5 & 0.727 \\
\hline 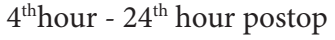 & 309.5 & -216.1 & 199.6 & 0.272 \\
\hline
\end{tabular}

Kruskal-Wallis test.

Group I: postoperative methylprednisolone

Group II: preoperative methylprednisolone

Group III: control; Preop=preoperation; postop=postoperation.

inflammatory cytokine that strongly correlates with pain; and the glucocorticoids turn out weaker than Nonsteroidal AntiInflammatory Drugs (NSAID) in reducing pain [8]. To overcome these weaknesses in postoperative open cholecystectomy, glucocorticoids can be administered together with NSAIDs, notwithstanding the possibility of postoperative nausea and vomiting must be considered.

\section{Conclusion}

Preoperative intravenous injection of methylprednisolone reduced the IL-6 level significantly, but not significantly reduce $P \mathrm{PE}_{2}$ level in open cholecystectomy surgery. The decreased values of IL- 6 and $P \mathrm{PE}_{2}$ postoperatively compared to those levels given preoperatively show a decrease in pain. Methylprednisolone administered intravenously before open cholecystectomy is able to decrease postoperative pain.

\section{Competing interests}

The authors declare that they have no competing interests.

\section{Authors' contributions}

\begin{tabular}{|l|c|c|}
\hline Authors' contributions & S & HSY \\
\hline Research concept and design & $\checkmark$ & $\checkmark$ \\
\hline Collection and/or assembly of data & $\checkmark$ & -- \\
\hline Data analysis and interpretation & $\checkmark$ & $\checkmark$ \\
\hline Writing the article & $\checkmark$ & $\checkmark$ \\
\hline Critical revision of the article & -- & $\checkmark$ \\
\hline Final approval of article & $\checkmark$ & $\checkmark$ \\
\hline Statistical analysis & $\checkmark$ & $\checkmark$ \\
\hline
\end{tabular}

\section{Acknowledgement}

We thank all operative-room-nurses and residents for their help during the study.

Publication history

EIC: D. John Doyle, Case Western Reserve University, USA.

Received: 04-Mar-2016 Final Revised: 19-Apr-2016

Accepted: 28-Apr-2016 Published: 06-May-2016

\section{References}

1. Buvanendran A, Kroin JS, Berger RA, Hallab NJ, Saha C, Negrescu C, Moric $\mathrm{M}$, Caicedo MS and Tuman KJ. Upregulation of prostaglandin E2 and interleukins in the central nervous system and peripheral tissue during and after surgery in humans. Anesthesiology. 2006; 104:403-10. | Article I PubMed

2. Watkins LR, Maier SF and Goehler LE. Immune activation: the role of pro-inflammatory cytokines in inflammation, illness responses and pathological pain states. Pain. 1995; 63:289-302. | PubMed

3. Romundstad L, Breivik H, Niemi G, Helle A and Stubhaug A. Methylprednisolone intravenously 1 day after surgery has sustained analgesic and opioid-sparing effects. Acta Anaesthesiol Scand. 2004; 48:1223-31. | Article | PubMed

4. Musba AMT, Tanra H, Yusuf I and Ahmad R. The preoperative single dose dexamethasone effect to pro-and anti-inflammatory cytokine during orthopedic surgery. Indian J Pain. 2015; 29:100-05. I Article

5. Dinarello CA. Anti-inflammatory Agents: Present and Future. Cell. 2010; 140:935-50. | Article | PubMed Abstract | PubMed Full Text

6. Kothari P, Pestana R, Mesraoua R, Elchaki R, Faisal Khan KM, Dannenberg AJ and Falcone DJ. IL-6-Mediated Induction of Matrix Metalloproteinase. J Immunol. 2013; 192:1-9.

7. Todd R, Cocanour CS. The immunology of Trauma. In:Asensio JA and Trunkey DD. Current Therapy of Trauma and Surgical Critical Care. Philadelphia:Mosby Elsevier. 2008; 677-81.

8. Rosseland LA and Romundstad L. Multimodal pain management with glucocorticoids: killing two birds with one stone or shooting sparrows with cannons? Acta Anaesthesiol Scand. 2013; 57:819-22. | Article | PubMed

\section{Citation:}

Suwarman S and Yuwono HS. Postoperative pain inhibition by preoperative methylprednisolone in open cholecystectomy with the assessment of IL-6 and PGE J Anesthesiol Clin Sci. 2016; 5:3.

http://dx.doi.org/10.7243/2049-9752-5-3 